\title{
A mentális egészség újradefiniálásának irányába - cikkismertetés
}

\author{
Toward a new definition of mental health - paper review
}

Ismerteti: Maczali Katalin $\square$

Állami Egészségügyi Ellátó Központ

Szerzők: Galderisi S, Heinz A, Kastrup M, et al

Megjelenés: World Psychiatry. 2015 Jun; 14(2): 231-233.

doi: 10.1002/wps.20231

Beküldve: 2018. 02. 01.

doi: 10.24365/ef.v59i1.230

Kulcsszavak: mentális egészség, definíció

Keywords: mental health, definition

A bemutatott tanulmány céljaként tǔzte ki a mentális egészség egy új fogalmának kialakítását, melyhez számos definíció tanulmányozásán keresztül vezetett az út.

$\mathrm{Az}$ első és legáltalánosabb mentális egészség definíciót a WHO alkotta meg, mely így szól:

„a jóllét olyan foka, amelyen az egyén megvalósítja képességeit, meg tud küzdeni az élet mindennapos nehézségeivel, eredménnyel és gyümölcsözően képes dolgozni, valamint hozzá tud járulni saját közösségéhez."

A mentális egészséget gyakran a "jólléttel”, pozitív faktorokkal határozzák meg, azonban a jó mentális egészségben élő egyének is élhetnek meg negatív érzéseket. Ezekkel a hedonikusi és eudaimonikusi megközelítésekkel azonban felmerül a kockázata annak, hogy a nehezebb élethelyzetben lévő, akár csak a stresszhelyzetet megélő kamaszokat is kizárja a mentális egészség definíciójából.

Szintén kockázatot jelent a hatékony munkavégzést kulcsfaktorként megjelölni, hiszen így azon egyének, akik fizikai állapotuk vagy épp diszkrimináció miatt nem képesek elhelyezkedni, esetleg nem számíthatnak mentálisan egészségesnek.

Ezeknek az elméleteknek a tanulmányozását követően, egy olyan fogalmi keret felvázolását tǔzték ki célul a szakértők, mely lehetőséget ad egyes érzelmi állapotok „nem tökéletes funkcionálásának".

Így a következő definíció született:

„A mentális egészség a belső egyensúly dinamikus állapota, mely lehetővé teszi az egyéneknek, hogy képességeiket a társadalom univerzális értékeivel összhangban használják. Alapvető kognitív és társadalmi készségek: a képesség, hogy felismerje, kifejezze és szabályozza az egyén az érzéseit, és hogy együtt érezzen másokkal; rugalmasság és megküzdési képesség váratlan élethelyzetekkel és

' Hedonizmus: Olyan filozófiai irányzat, mely alapelve a boldogságkeresés, és a boldogságot az élvezetekkel azonosítja.

ii Eudaimonia: Olyan filozófiai irányzat, mely alapelve a boldogságkeresés, azonban a boldogságot az erények gyakorlásával azonosítja. 
funkcionálás a társadalmi szerepekben; valamint a harmonikus kapcsolat a test és lélek között fontos részei a mentális egészségnek, melyek különböző mértékben hozzájárulnak a belső egyensúly állapotához."

A mentális egészség fogalma gyakran változik az adott ország kultúrájának hatására, azonban a fenti meghatározás magába foglalja a társadalom univerzális értékeit, melyek kultúrától függetlenek (pl. mások és önmagunk szabadságának tisztelete). A koncepció elfogadja az esetleges negatív érzelmek megélését, és a belső egyensúly által a felvázolt komponenseknek nem szükséges egyenlő mértékben hozzájárulni a mentális egészség eléréséhez, pusztán úgy kell kiegészíteniük egymás gyengeségeit, hogy az egy egyensúlyi állapotot eredményezzen.

\section{TANULSÁGOK A HAZAI SZAKEMBEREK SZÁMÁRA}

Jelenleg hazánkban a legáltalánosabban elfogadott mentális egészség fogalom a WHO által jegyzett definíció, ami jelentős fejlődés a korábban elfogadott megfogalmazásokhoz képest (ezek a mentális egészséget a mentális betegség hiányaként értelmezték). Szükség van azonban itthon is az új definíciók adaptálásra, melyek rugalmasabban, nem túl szigorú keretek és kulcsfaktorok közé sorolják a mentális egészség állapotát. 